\title{
KOMENTARZ DO WYWIADU Z DMITIRM LEVITINEM
}

Michał Rogalski

Uniwersytet Warszawski

Umieszczenie w numerze poświęconym wędrującym pojęciom wywiadu z osobą, która zachowuje dystans wobec traktowania badań historycznych jako opowieści o pojęciach, może wydawać się nieuzasadnione. Tak jest jednak tylko na pierwszy rzut oka. Dmitri Levitin dystansuje się od tezy o wędrowaniu pojęć, a jednocześnie wskazuje na rzeczy, które jego zdaniem wędrują naprawdę: książki. Bada on okres wczesnej nowoczesności (early modernity) - XVII i XVIII wiek - aby poznać reguły dokonującego się wtedy dynamicznie rozwoju nauki, filozofii i teologii. Skupia się przy tym na kluczowych, jego zdaniem, sposobach przekazu wiedzy. Stąd nacisk kładziony na badanie ówczesnej tradycji uniwersyteckiej, które w pewnym uproszczeniu sprowadza się do studiowania i porównywania ze sobą książek z tamtego okresu.

Stoi za tym następujące założenie: ludzie, aby zdobywać i poszerzać swoją wiedzę i wyobrażenie o świecie, kupowali i czytali książki, czynili notatki na marginesach, korespondowali z innymi ludźmi, zdając sprawę ze swoich lektur i konfrontując własne doświadczenie czytelnicze z doświadczeniami innych. Zmiana paradygmatu naukowego na bardziej empiryczny, rozwój metod hermeneutycznych oraz postępy uwalniającej się od wpływów myślenia scholastycznego filozofii, które miały miejsce w wiekach XVII i XVIII, dokonały się właśnie dzięki temu. Levitin, przyjmując taki punkt wyjścia, zajmuje się wiedzą i myśleniem, a więc w gruncie rzeczy także pojęciami. Ruch pojęć - przemianę ich znaczeń - umożliwia to, że pewna posiadająca znaczenie w naukowym świecie grupa osób zaczęła poświęcać czas na lekturę określonej książki. Levitin analizuje sposób myślenia ludzi wczesnej nowoczesności o klasycznych dziełach teologicznych 
i filozoficznych starożytności, które pojawiały się bardzo licznie na europejskim rynku książki na skutek rozwoju technik drukarskich i doskonalenia przez ówczesnych badaczy filologicznych umiejętności wydawania krytycznych edycji dzieł.

Tak głębokie przywiązanie do materialnych przedmiotów, stanowiących źródła w pracy historyka, jest możliwe tam, gdzie historia łagodnie obeszła się z dziedzictwem historycznym. Tym bowiem, z czego korzysta Levitin, np. w badaniach nad Newtonem, nie jest jakikolwiek egzemplarz pracy poświęconej, dajmy na to, Ojcom Kościoła, ale konkretny egzemplarz należący do Newtona, na którym znajdują się jego notatki. W sytuacji takiego bogactwa archiwaliów można pozwolić sobie na dystans wobec skupiania się w badaniach historycznych na historii pojęć.

Postawa przyjmowana przez Levitina przynależy ponadto do określonej anglosaskiej tradycji uprawiania historii idei i historii intelektualnej. Levitin studiował w Cambridge m.in. u Quentina Skinnera, współtwórcy stanowiska metodologicznego w badaniach nad historią idei politycznych określanego mianem „szkoły Cambridge”. Skinner w założycielskim dla tej formacji tekście Znaczenie i rozumienie w historii idei (1969) postuluje wypracowanie nowej drogi analizy unikającej dwóch skrajności: ahistorycznej gry wiecznych pojęć dla uzyskania rozległych syntetycznych opowieści oraz sprowadzania określonych formacji myślowych jedynie do roli wypadkowej historycznego kontekstu ich powstania (Skinner 2014). Skutkuje to dystansem wobec stosowania przez historyków kategorii przekrojowych i tworzących wyraźne dychotomie, jak na przykład „starożytny” - „nowoczesny” czy „oświeceniowy” - „postoświeceniowy” (Boyd 2014: 425). Wyjście od jednostkowej analizy może jednak prowadzić ku ujęciom szerszym i syntetycznym. Szczegól stanowi drogę do budowania historycznej narracji. Te same cechy widać również w myśleniu Levitina.

Sądzę jednak, że sposób uprawiania przez niego historii należy zestawić z jeszcze jednym kontekstem. W swoim przywiązaniu do materialności źródeł myślenie Levitina bliskie jest koncepcji nauki (choć z oczywistych powodów bezpośrednio z nią nie związane) sformułowanej przez Kazimierza Twardowskiego w rozprawie O czynnościach $i$ wytworach. Killeu uwagach z.pogranicza psychologii, gramatyki i logiki z roku 1911. Tekst ten miał być - jak pokazują badania Wioletty Miśkiewicz - próbą zbudowania wspólnej optyki filozoficznej dla kolejnych pokoleń uczniów Twardowskiego. Twardowski starał się w ostatniej części tego tekstu zbudować opis sposobu, w jaki dokonuje się wymiana wiedzy, w kategoriach czynności i ich wytworów.

${ }^{1}$ Por. artykuł Jerzego Szackiego w niniejszym tomie. 
Tym bowiem, z czym spotykamy się czytając lub zdobywając wiedzę, są oczywiście wytwory - książki, preparaty, zdjęcia, eksponaty itd. Są to przy tym wytwory - wedle pojęciowania Twardowskiego - trwałe, które „oderwały się" od swoich czynności. U ich podstaw leżą jednak pewne czynności, które musiały zostać wykonane, aby określony wytwór powstał. Nie muszą one wpływać na nasz odbiór uniezależnionego i trwałego wytworu, ale pytanie o czynności staje się bardzo istotnym pytaniem dla historyka nauki czy historyka idei. Można bowiem uprawiać te dyscypliny jako historię wytworów, które się ze sobą zestawia i porównuje, ale umyka wtedy istota procesu rozwoju intelektualnego. Aby powstała praca A inspirowana wcześniejsza pracą $B$, tworzący pracę A musi wykonać szereg określonych czynności (zdobyć pracę B, przeczytać ją, zanotować wnioski z lektury itp.). Czasem - z uwagi na niezależność wytworów trwałych od czynności prowadzących do ich powstania - ów szereg działań nie ma większego znaczenia dla treści dzieła-wytworu, a czasem wpływa na nia w istotny sposób. Odcięcie się od działań konkretnych historycznych osób, stojących za książkami czy stanowiskami, nie może być ani automatyczne, ani trywialne. Co się musiało stać, aby dokonała się taka a taka zmiana w myśleniu, taki a taki rozwój pojęć lub metod? Jakie czynności miały miejsce, aby powstał taki a taki wytwór? Takie pytania stawia również Dmitri Levitin.

Bibliografia:

/// Boyd R. 2014. Cambridge School, [w:] The Encyclopedia of Political Thought, red. M.T. Gibbons i in., t. 1, Wiley, s. 422-427.

/// Skinner Q. 2014. Znaczenie i rozumienie w historii idei, przeł. F. Biały, „Refleksje", nr 9, s. 129-168. 